\title{
Towards effective Teaching and learning ESP in mixed classes: Students' interest, challenges and remedies
}

\author{
Twahirwa Jean Bosco ${ }^{1 *}$, Bazimaziki Gabriel${ }^{2}$, Mukadisi Florence ${ }^{3}$, Nyandwi \\ Gilbert $^{4}$
}

\footnotetext{
${ }^{1,2}$ University of Rwanda, Department of Humanities and Language Education, P.O Box 55 Rwamagana, Rwanda ${ }^{3}$ Department of Languages and Entrepreneurship, Rwanda Polytechnic / College of Musanze, P.O.Box 226, Musanze, Rwanda ${ }^{4}$ University of Rwanda, Department of Humanities and Language Education, P.O Box 55 Rwamagana, Rwanda

* Main Author
}

\begin{abstract}
This study reports on students' interest in English for Specific Purposes (ESP) and challenges impeding their effective learning. The study is anchored on Richards' Communicative Language teaching theory (CLT) framed on principles of language teaching and learning. Both qualitative and quantitative approaches were used. A four Likert Scale questionnaire was used to gather information from forty - five respondents determined basing on Morgan and Krejcie's approach. Analysis revealed that despite that majority of students are interested in English for Specific purposes, factors such as fear of practice, few or lack of appropriate facilities, class size affect teaching and learning. It was recommended that the three parts concerned with the teaching and learning play their parts to grapple with these challenges.
\end{abstract}

Keywords- English, interest, Challenges, perceptions, impediment, learning, ESP, mixed classes, Communicative Language Teaching.

\section{INTRODUCTION}

The question of how students learn and how teachers bring about learning cannot be answered as education deals with specific purposes and contexts that differ from each other with students who are diverse in all aspects(Fry et al, 2009). Language teaching and learning aim primarily to enabling learners communicate their ideas in that language with ease. Learning and teaching English for Specific Purpose (ESP) in higher education intends to help students be equipped with more advanced language tools or develop all language critical skills of speaking, listening, reading and writing. When students master these four language skills, they can now be successful in their academic journey as English has become not only a medium of instruction but also a subject to be taught at tertiary level of Education in many parts of the globe. However, at university level, teaching and learning can be affected by various factors including students' personal challenges and institution's conditions. Students' engagement and their interests in the subject by linking what they learnt to the world issues (Burkšaitienè and Šliogeriene, 2018) hold an important part among the positive factors while low level of English probably resulting from inadequate training in the previous studies in tandem with learning environment, militate against effective teaching and learning as both slow down the teachers and impede them to carry it out effectively. This being, students' interest in ESP and related challenge pause a number of questions that need be explored in a study based on Richards' Communicative Language teaching theory (CLT) as framed on principles language teaching goals, how learners learn it, the kinds of classroom activities that best facilitate language learning, and the roles of both teachers and learners in the classroom. 


\section{BACKGROUND AND PROBLEM STATEMENT}

Currently, teaching English for specific purposes in higher education is being dictated mostly by the influence of globalization and internationalization (Duyen, 2019). Higher institutions in Rwanda are not exception and are committed to helping their future graduates be equipped with English language skills to use in their various work fields namely education and other related occupational businesses. Richards (2006) postulates that Communicative language teaching sets as its goal the teaching of communicative competence; the knowledge we have of a language that accounts for our ability to produce sentences in it. It is this communicative competence that is affecting the teaching and learning of English as a foreign language in Higher Education in one way or another. As an international language that serves for many purposes worldwide, English is not only taught in Rwandan Education as a subject but also a medium of instruction since the post genocide period. It is also an official language besides the three other languages namely French, Swahili and Kinyarwanda that are currently used for official purposes. Across various parts of the globe, for enhanced learning in higher education environment to be ensured, new methodologies of teaching and learning including problem-solving, project-based, portfolio-based teaching and learning, collaborative learning and technologyenhanced learning, web-assisted learning have been increasingly adopted by higher education institutions across the globe(Burkšaitienè and Šliogerienė,, 2018). These new methodologies need be applied in congruent with students' level and competencies, learning environment and available facilities. Elsewhere, students in University of Rwanda, like any other students whose first language is not English, have a range of communication needs in academic context (Rupert, 2016) but at the end of their studies they are still grappling with difficulties linked with inadequate communication be it in written and spoken languages. Having been trained in English and taught English as a subject, it is still hard for them to minimize language errors which means expectations while teaching them English for specific purpose are not met. Inherently, while Bazimaziki (2018) recommended that efforts be made to practice and improve English language for effective communication, it is not actually done at the expected level due to various factors. To a certain extent, this is rooted in learners' low communication competence coupled little interest while Kimbouala et al.(2018) believe that lack of motivation and difficulties to express themselves in the target language militate against the effective learning. Discussing similar issue, Sumipo (2019) asserts that the paradigm shift of modern education which stresses on economic demands and fields of specialization calls for teaching of English for the obvious reason of equipping the students with the kind of English which assures immediate employment in their chosen fields. English for Specific Purposes (ESP) is taught in higher education for similar aims to help students be equipped with English communication skills that would enable them to carry out their works conversantly. Against this background, the researchers deemed necessary to explore students' perceptions of their interest in ESP, challenges affecting them and way to grapple with them for its effective learning.

\section{Aims and Scope}

The study is concerned with English for Specific Purposes, one of the cross cutting subjects taught students of University of Rwanda, College of Education. The researchers involved year two students from Science and social Science combinations for the Academic Year 2018/2019. Due to time and space, the researchers involved a small group at a particular occasion during the teaching and learning cession. The researchers wanted to explore students' perceptions and reflection on their interest in learning ESP, identify challenges affecting their learning and explore possible remedies. The study seeks to answer the following questions: (1) How far are students interested in learning English for Specific Purposes? (2) What are students' reflections about the challenges impeding them to learn ESP effectively? (3) How can these challenges be mitigated? The researchers concur with Richards (2006) who posits that ESP courses are designed to address the language needs of university students, nurses, engineers, restaurant staff, doctors, hotel staff, airline pilots, and so on.

\section{LITERATURE REVIEW}

English for Specific Purposes has won a wide ground in the area of research on language education in various parts of the globe. Learning and teaching English for Specific Purposes (ESP) go along with globalization and internationalization where English holds an important part as a global language used in many if not all life domains. Duyen (2019) explored teacher's perceptions as regard ESP assessment and come up with the conclusion that ESP should help students develop not only their language competence but also critical thinking and problem solving skills information searching, 
group-work and presentation skills. ESP lays ground for English for Academic Purposes (EAP). The two subjects aim concurrently to enhancing learners' proficiency so that they can feel confident when using English in and outside academic activities. It is contended that most of EAP users do not have English as their first language (Frankenberg, 2018) and novice EAP users would benefit much from much exposure to that language even when their L1 is English. As such, it is purposeful for students of higher institutions to take it since it is a channel through which they would pursue their chosen courses (Rupert, 2016) in tandem with their institutions' policies each. This is a view stressed in Udu (2019) that language learning in context is more meaningful to the students than general English, by integrating the four basic language skills allowing students opportunities to participate in their learning.

Eventually, most of the learners of English as a foreign language (EFL) are greatly affected by various factors militating against mastery of that language. These factors include - but are not limited to, personal and situational factors as pointed out by Le Van \&Tran Thị Trang (2019) such as low level of English proficiency, related with lack of enough knowledge of how to use communicative strategies. As a result of their previous studies, they are still having difficulties in English. It is a demotivating factor to improving their speaking skills linked lack of self-confidence due to fear of speaking practice. Active participation is another factor militating against foreign language learning. Having been familiar with communication in their mother or vernacular language, learners may be demotivated to learn over time if they find the lessons dry and run of the mill at every lesson over time (Mahendran, 2019). In the view of this author, learning this does not bode well to the learning and practice of English language skills as without actively participating in the lessons, learners may mentally 'switch off' and lose 'steam' whilst they are in the course of learning.

Put another way, successful foreign language learning is affected by learning environment in tandem with the learners' ability to participate actively in their learning by practice. Class size and mixed students with different levels of proficiency and different interest in English language is another factor that challenges the successful learning. In fact, when English for Academic purposes is taught in class with students from differing combinations, it can be a big load for a teacher to successfully put them at the same pace. Regardless of teaching experience or a place where one teaches, each teacher faces challenges on a regular basis and frequently face with challenges such as large and mixedability groups of students, under motivated students, underappreciation by students and faculty management, time management, lack of ready-made course materials and insufficient content knowledge or learners' own competence before entering university. All these factors impact negatively learners' motivation and performance whereby the less able students encounter more difficulties than the more able ones in EFL learning (Lenard \& Lenard, 2018; Kimbouala et al., 2018); Le Van \&Tran Thị Trang (2019) . It would be harder if not impossible for a teacher to teach effectively large and mixed groups of students than handling a smaller class with learners having almost the same level. Considering the viewpoints of the above authors, there is likelihood to content that any single factor be it related to teacher or students can impact the teaching and learning activity either negatively or positively. Successful teaching and learning English, further, requires that both teacher and learner get prepared in a conducive environment with facilities at their disposal.

\section{THEORIES AND METHOD}

For any teaching and learning activity to be carried out effectively, both the teacher and learners must play their part each in tandem with the learning environment. The underlying theory in this study is Communicative Language Teaching (CLT) as discussed in Richards (2006). According to him, the central premise for advocates of CLT is that many learners needed English in order to use it in specific occupational or educational settings. For them, it would be more efficient to teach them the specific kinds of language and communicative skills needed for particular roles, (e.g., that of nurse, engineer, flight attendant, pilot, biologist, etc.) rather than just to concentrate on more general English. This led to the discipline of needs analysis - the use of observation, surveys, interviews, situation analysis, and analysis of language samples collected in different settings in order to determine the kinds of communication learners would need to master if they were in specific occupational or educational roles and the language features of particular settings. The focus of needs analysis is to determine the specific characteristics of a language when it is used for specific rather than general purposes. Such differences might include, differences in vocabulary choice, differences in grammar, differences in the kinds of texts commonly occurring, differences in functions and differences in the need for particular skills. ESP courses soon began to appear 
addressing the language needs of university students, nurses, engineers, restaurant staff, doctors, hotel staff, airline pilots, and so on. Communicative language teaching can be understood as a set of principles about the goals of language teaching, how learners learn a language, the kinds of classroom activities that best facilitate learning, and the roles of teachers and learners in classroom. Researchers anchored on CLT in this study following the view of Batuto \& de La Pena (2019) that in CLT, students centered activities such as role playing, drama presentations, and panel discussion improve students" speaking skills. Thinking in the same way during the teaching and learning of ESP can lead to improving students communication competences.

In this study, among 50 students present at a particular occasion, 45 were sampled randomly. This sample size was determined basing on Morgan and Krejicie's (1970) approach. A four Likert Scale (Strongly agree = S.A; Agree= $A ;$ Disagree $=D$ and strongly disagree $=S D$ ) questionnaire was used as a data collection instrument. Both qualitative and quantitative analyses were used as the study involved numerical data interpreted using SPSS (Statistical Package for Social Sciences) tool. Information were gathered following three topics shaping the questionnaire based on the three research questions. Theme one was concerned with the students' interest in ESP. Following closely, the second topic was concerned with the challenges faced by students during the ESP lesson. Besides, the researchers used three open questions to collect information related with the role of the learners, teachers and the institution to remedy these challenges. Information gathered were presented in tables following themes that generated them. Discussion of findings was done basing on the main aim of teaching a language which is communication in it.

\section{PRESENTATION OF RESULTS}

In this section, the researchers present the data as collected from 45 respondents. These are concerned with three important topics namely demographic situation of respondents, then their interest in ESP and challenges impeding them to learn that course effectively; and finally possible remedies to mitigate these challenges. Researchers recorded information as provided by respondents without any addition nor reduction.

Table 1: Table showing the demographic situation of respondents: gender age and combinations

\begin{tabular}{|l|l|l|l|}
\hline \multicolumn{2}{|c|}{ Categories } & \multicolumn{2}{l|}{ Frequency and percentages } \\
\cline { 3 - 4 } \multicolumn{2}{|c|}{} & Frequency & \% \\
\hline Gender of respondents & Male & 33 & 73.3 \\
\cline { 2 - 4 } & Female & 12 & 26.7 \\
\hline Total & $\mathbf{2}$ & $\mathbf{4 5}$ & $\mathbf{1 0 0}$ \\
\hline \multirow{5}{*}{ Age of respondents } & 21 & 7 & 15.6 \\
\cline { 2 - 4 } & 22 & 7 & 15.6 \\
\cline { 2 - 4 } & 23 & 13 & 28.9 \\
\cline { 2 - 4 } & 24 & 8 & 17.8 \\
\cline { 2 - 4 } & 25 & 4 & 8.9 \\
\cline { 2 - 4 } & 26 & 3 & 6.7 \\
\cline { 2 - 4 } & 27 & 3 & 6.7 \\
\hline Total & $\mathbf{7}$ & $\mathbf{4 5}$ & $\mathbf{1 0 0}$ \\
\hline Combinations of & EEE & 19 & 42.2 \\
\cline { 2 - 4 } respondents & MPE & 15 & 33.3 \\
\cline { 2 - 4 } & MCsE & 11 & 24.4 \\
\hline Total & $\mathbf{3}$ & $\mathbf{4 5}$ & $\mathbf{1 0 0}$ \\
\hline
\end{tabular}


As revealed in the above table, among 45 respondents, majority, that is 33 which is $73 \%$ are male while the remaining 22 equivalent to $26.7 \%$ are female. As regard their ages, it is important to mention that there are 7 categories ranging between 21 and 27. As such, majority of respondents are aged 23 which represents $28.9 \%$. The next category is those aged 24 equivalent to $17.8 \%$, then those aged 21 and 22 are 14; 7 for each category which makes $31.2 \%$ ( 15.6 for each category); Following closely, respondents aged 26 and
27 are 6 equivalent to ( $13.4 \%)$ as each of the two categories counts 3 representing $6.7 \%$. The last but not the least category is the one with 8 respondents aged 24 which represents $17.8 \%$ of the total number of respondents. Concerning their disciplines, three combinations categorise them such as Economics -Entrepreneurship Education (EEE); Mathematics-Physics Education (MPE) and Mathematics - Computer Sciences Education (MCsE).

Table 2: Table presenting respondents' interest in English for Academic Purpose (ESP)

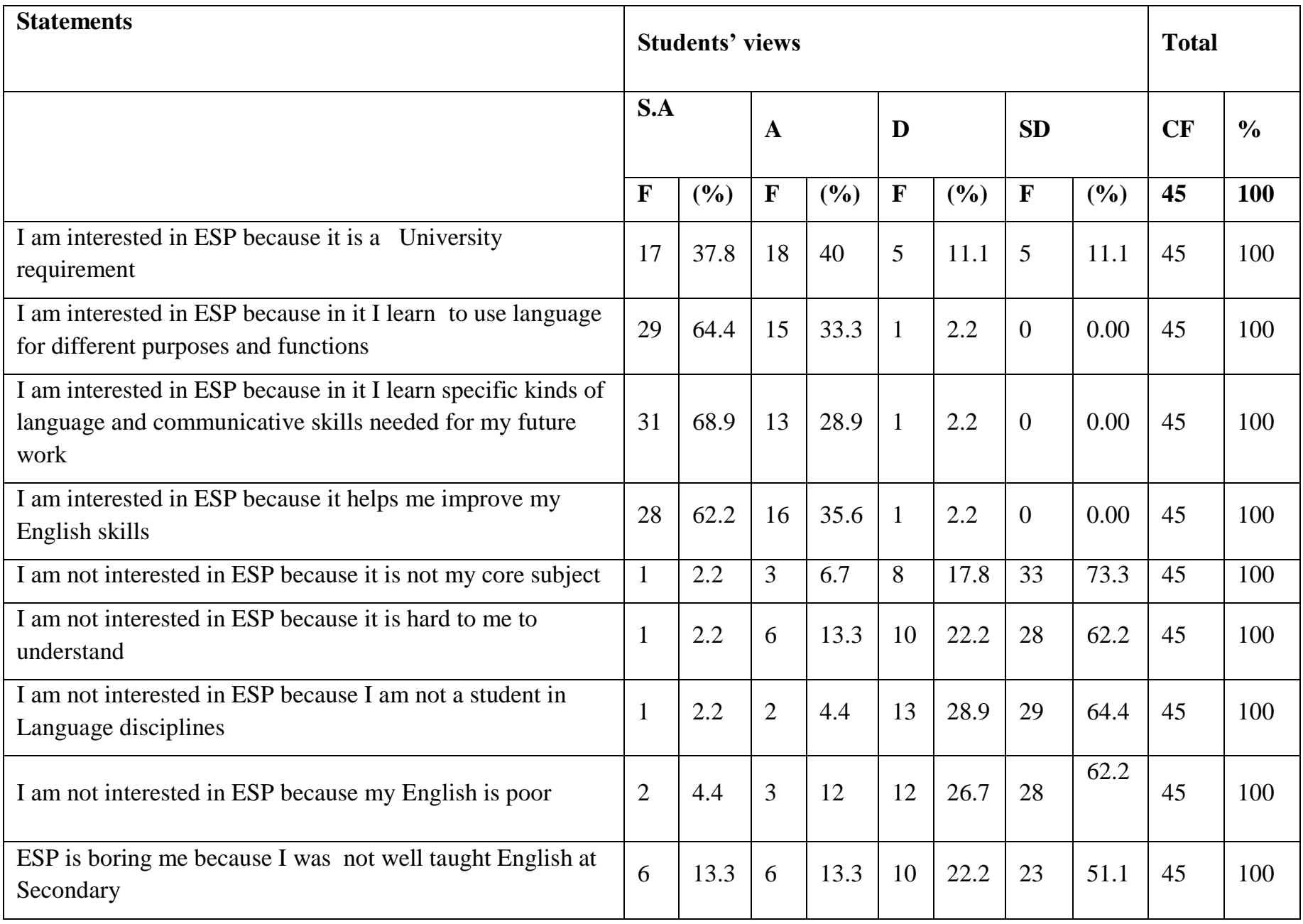


Table 3: Table showing respondents' views about factors militating against the effective learning of ESP

\begin{tabular}{|c|c|c|c|c|c|c|c|c|c|c|}
\hline \multirow{3}{*}{ Statements } & \multicolumn{8}{|c|}{ Students' views } & \multirow{2}{*}{\multicolumn{2}{|c|}{ Total }} \\
\hline & \multicolumn{2}{|c|}{ S.A } & \multicolumn{2}{|l|}{$\mathbf{A}$} & \multicolumn{2}{|l|}{$\mathbf{D}$} & \multicolumn{2}{|c|}{ S.D } & & \\
\hline & $\mathbf{F}$ & $\%$ & $\mathbf{F}$ & $\%$ & $\mathbf{F}$ & $\%$ & $\mathbf{F}$ & $\%$ & C.F & $\%$ \\
\hline $\begin{array}{l}\text { Fear of practice is a big challenge to me in } \\
\text { learning ESP }\end{array}$ & 16 & 35.6 & 17 & 37.8 & 9 & 20 & 3 & 6.7 & 45 & 100 \\
\hline I don't learn ESP well because of big class size & 12 & 26.7 & 16 & 35.6 & 10 & 22.2 & 7 & 15.6 & 45 & 100 \\
\hline $\begin{array}{l}\text { Few speaking practical exercises impede my } \\
\text { effective learning of ESP }\end{array}$ & 14 & 31.1 & 22 & 48.9 & 5 & 11.1 & 4 & 8.9 & 45 & 100 \\
\hline $\begin{array}{l}\text { Mixed classes from different combinations } \\
\text { impedes my learning ESP }\end{array}$ & 7 & 15.6 & 16 & 35.6 & 13 & 28.9 & 9 & 20 & 45 & 100 \\
\hline $\begin{array}{l}\text { Lack of teaching and learning tools affects my } \\
\text { learning of ESP }\end{array}$ & 11 & 24.4 & 18 & 40 & 16 & 35.6 & 0 & 0 & 45 & 100 \\
\hline $\begin{array}{l}\text { My low English level is a big challenge tome to } \\
\text { follow the teacher in ESP }\end{array}$ & 12 & 26.7 & 11 & 24.4 & 12 & 26.7 & 10 & 22.2 & 45 & 100 \\
\hline Teaching methodology in ESP challenges me & 10 & 22.2 & 10 & 22.2 & 19 & 42.2 & 6 & 13.3 & 45 & 100 \\
\hline $\begin{array}{l}\text { My little interest in ESP is a challenge that affects } \\
\text { my learning }\end{array}$ & 5 & 11.1 & 9 & 20 & 16 & 35.6 & 15 & 33.3 & 45 & 100 \\
\hline
\end{tabular}

Results from open questions: How to cope with challenges impeding effective learning of ESP

In this section, the researchers present the respondents' views of what should be done to cope with the challenges and factors militating against the effective teaching and learning of ESP (English for Specific Purposes). To gather information related with the point made here, the researchers posed three open questions such as (1) what should learners do to cope with difficulties encountered in learning ESP? (2) What should be the role of teachers of ESP to remedy the situation? and (3) what can be the role of institution to mitigate these challenges? Foer these questions, respondents' views were presented as follow:

\begin{tabular}{|c|c|c|}
\hline Stud & role & ole \\
\hline $\begin{array}{l}\text { Reading a lot to improve and } \\
\text { increase vocabulary } \\
\text { Increase speaking practices } \\
\text { Build a self-confidence when } \\
\text { speaking before the public } \\
\text { Avoid fear of practising speaking } \\
\text { and attend class regularly without } \\
\text { dogging or being late } \\
\text { Stick to English in their daily } \\
\text { communication particularly at the } \\
\text { college } \\
\text { Be active and engage more efforts } \\
\text { to communicate in English with }\end{array}$ & $\begin{array}{l}\text { Promote speaking practical } \\
\text { exercises } \\
\text { Vary teaching and learning } \\
\text { methodologies } \\
\text { Advise learners what to do } \\
\text { Advocacy for time table to place } \\
\text { ESP during morning hours } \\
\text { Try motivate their learners and } \\
\text { know their gaps so as to help them } \\
\text { Promote presentations and more } \\
\text { writing exercises } \\
\text { Enhance debate to help students }\end{array}$ & $\begin{array}{l}\text { Provision of convenient teaching } \\
\text { and learning materials fitting for } \\
\text { ESP } \\
\text { Increase the number of competent } \\
\text { and qualified teachers of ESP } \\
\text { Regular trainings to the ESP } \\
\text { lecturers } \\
\text { Reduce the number of students } \\
\text { attending in the same classroom at } \\
\text { the same time and classes and equip } \\
\text { them with facilities like internet, } \\
\text { microphones, loudspeakers, chairs } \\
\text { Promote the culture of debates }\end{array}$ \\
\hline
\end{tabular}




\begin{tabular}{|c|c|c|}
\hline $\begin{array}{l}\text { their peers } \\
\text { Feel more interested in ESP as it is } \\
\text { an important subject for their } \\
\text { Academic life } \\
\text { Focus on what they wish to know } \\
\text { but don't know } \\
\text { Form different clubs where English } \\
\text { must be used } \\
\text { Avoid the complex of fearing to } \\
\text { make mistakes } \\
\text { Use English only in class especially } \\
\text { when asking the teacher or } \\
\text { interacting where they do not } \\
\text { understand well } \\
\text { Attend regularly public speeches }\end{array}$ & $\begin{array}{l}\text { enhance their language skills } \\
\text { Organise small groups of less than } \\
10 \text { students } \\
\text { Create as many as possible } \\
\text { opportunities for students to express } \\
\text { themselves and practice the little } \\
\text { English they have } \\
\text { Should use simple English that is at } \\
\text { the level of their students } \\
\text { Promote debate among students } \\
\text { during the teaching and learning } \\
\text { ESP } \\
\text { Use regularly audio - visual } \\
\text { materials for students to be familiar } \\
\text { with English use in different context } \\
\text { Manage their class effectively }\end{array}$ & $\begin{array}{l}\text { among students } \\
\text { Encourage speaking clubs for all } \\
\text { combinations and support them } \\
\text { regularly } \\
\text { Make a follow up and supervision } \\
\text { of how ESP is taught and solve the } \\
\text { related problems } \\
\text { Set rules for students to use English } \\
\text { as an academic language and tell } \\
\text { them the role of ESP in academic } \\
\text { life and even beyond } \\
\text { Organise intra-college competition } \\
\text { on Speaking English to motivate } \\
\text { students }\end{array}$ \\
\hline
\end{tabular}

\section{DISCUSSION OF FINDINGS}

Findings in this study were discussed based on the primary aim of language learning. In the view of Bazimaziki (2018), the primary aim of language learning is communication and it is achieved if learners want to practise language as the saying goes that practice makes perfect. Looking into the respondents' views, table one revealed a lot as regard the students interest in English for Specific Purposes (ESP). As can be seen, majority of students 28 over 45 (64.4\%) strongly agree with the statement about their interest in ESP while $15(33.3 \%)$ agree with the statement; thus a total of 97.7\% respondents reveal that ESP is important to them because it helps them to learn how to use language for different purposes and functions. In the same token, 31 over 45 (68.9\%) support that they attach a very big interest in ESP (strongly agree) and $13(28.9 \%)$ agree that they are interested in it. As such, a total of 44 over $45(97.8 \%)$ are interested in ESP because through it they learn specific kinds of language and communicative skills needed for my future work. $1(2.2 \%)$ disagrees with the statement while none of them strongly disagrees with the statement. Following closely, 28 over $45(62.2 \%)$ strongly agree and 16 (35.6) agree that they are interested in ESP because it helps them improve their English skills. 1 respondent (2.2\%) disagree and none strongly disagrees with the statement. Taken together 44 over 45 students $(97.8 \%)$ revealed that they are interested in ESP as it is a way through which their communication skills in English improve.
From this situation, it is worthwhile confirming that the role of ESP to science students must not be undermined. Both teachers and students in the science disciplines must not undermine the role that subject holds in education; do their best and play their roles for each to effectively teach and learn this subject which would help graduates not only in their academic life but also for their future life after graduation. It is a subject which is not only a university requirements to graduate but also a subject that will help university leavers to integrate with the world market mainly because English has become a business language, a global language, a language leading in technology, and a medium of instruction for various disciplines in many parts of the globe from pre-primary to tertiary education.

According to Gớlovó (2007) teaching English for specific purpose (ESP) at University is not an easy task especially when it is taught as a free choice subject among heterogeneous mixed- abilities and large classes. Concerning the statement related with lack of interest in ESP, respondents disagreed to a higher extent which reflects the idea already pointed out earlier. In fact, 5 over 45 respondents $(11 \%)$ in total say they strongly agree and 14 over 45 respondents $(36.4 \%)$ agree that they are not interested in ESP because of various reasons. 4 respondents $(8.9 \%)$ give the reason that it is because ESP is not their core subject; $7(15.5 \%$ say that ESP is hard to them while $3(6.6 \%)$ state the reason that it is because they are not students from language disciplines and $5(16.4 \%)$ show that their poor 
English cause them to lose interest in English. 12 over 45 (26.6\%) reveal that they were not well taught English at secondary which make them be bored during ESP classes. All these factors cannot be undermined. Students generally lose interest in a subject due to one of these reasons. Some students decide to concentrate on core subjects and engage little energy for elective ones. This is not beneficial to them. No subjects override another. Rather, they are interdependent and complementary to one another in favour of the learner. A little knowledge or poor skills in a subject can be covered or improved by engaging more efforts than losing interests in it. Additionally, knowing one's weaknesses or gaps in a subject can be a good step to catch up instead of being bored. Conclusively, teachers are responsible for the remedy to these hurdles to help the learners achieve the subject learning outcomes and graduates attributes as well.

Having a look at table 3 showing respondents' views about factors affecting the effective learning of ESP, it was found that the fear of practice, few speaking practices and lack of enough teaching and learning tools outweigh other challenges. In fact, 16 over 45 (35.6\%) strongly agree and 17 (37.8\%) agree that fear of practice affects learning ESP. 9 (20\%) disagree while $3(6.7 \%)$ strongly disagree with the statement. 14(31.1\%) strongly agree and 22(48.9\%) agree that few speaking practical exercises impede effective learning of that subject while $5(11.1 \%)$ respondents disagree and $4(8.9 \%)$ strongly disagree with the idea. In the same connection, 11(24.4\%) respondents strongly agree and 18 (40\%) of respondents agree that lack of teaching and learning tools is a big challenge. Regarding class size as another challenge, 12(16.7\%) strongly agree and $16(35.6 \%$ agree while 10 (22.2\% disagree and $7(15.6 \%)$ strongly disagree. Mixed classes holds the next position whereby $7(15.6 \%)$ strongly agree and $16(35.6 \%)$ agree that different combinations mixed impede effective teaching and learning. Next comes a challenge related with students' level of English whereby $12(26.7 \%)$ strongly agree and $11(24.4 \%)$ agree that their low level of English affects their learning ESP subject. Concerning the teaching methodologies as another challenge, respondents $20(44.4 \%)$ totally agree with the statement in that $10(22.2 \%)$ strongly agree and other 10(22.2) agree. As can be seen in the above presentation, fear to practise a language greatly affect learners not only during the teaching and learning activities but also beyond the classroom. While it is commonly said that "Practice makes perfect" students who fear to practice perform hardly. Should they dare try and fail they would gradually know having learned from the mistakes made during their trial. The fact is when students strongly agree (48.9\%) that few practical exercises affect their learning imply that the need enough speaking practice so that they can improve their speaking skills which impede them to communicate effectively in different situations. This is the over leading aim of language learning as highlighted in Richards (2006) that is communication for their specific and occupational and educational roles. For the present study, students involved are being trained to become Science and social Sciences teachers. They are required to be well equipped with good command of English which is a medium through which they will be transmitting the "know what" and "know how" to the children of their country thus contributing to building it.

When respondents (44.4\%) stand that the methodologies of teaching ESP are among other factors that impede their effective learning, the implication is that strategies to teaching ESP need be changed or varied to solve the students' needs. In a study by Mohammad \& Eyad (2019) strategies that expose learners to second language are proposed such as avoidance of mother, promotion of the use of technology, lab models, voice tune, body language and Total Physical Response among others. Eventually, coupled with their low or poor English communication skills, the way the content is delivered can be a big matter that needs be catered for. Lecturing methods, for instance, does not create enough opportunities for learners to practice. Rather, Communicative Language Teaching( CLT) approach and similar methods involving the learner can hold a big room so that the learners can be trained and shaped into an individual demonstrating ability to analyse a situation, critically think about the way to solve it and present it in a conversant way. As such, assessment in ESP can adapt another mode where the learner must show that they are good communicators but not good content masters only.

Concerning information gathered through the three open questions, three parts are involved to cope with these challenges. Students, teachers and their institutions must bear the burden and feel that they are all responsible for the solution. It is important to point out that question one was concerned with the role of the students. Respondents suggested that students take time for reading to improve and increase their vocabulary. One can add that this should go hand in hand with using this new vocabulary in both writing and speaking speaking practices. In so doing, they must build a self-confidence when speaking before the public and avoid fear of making mistakes which often times complex them. 
Another thing to be done as students pointed it out is to attend class regularly without dogging or being late. Sometimes students dodge or absent themselves without any reason. This is connected with the factor of lack of interest in the course which affect them gradually. Another factor is lack of active participation where students look passively and overly depending on the teacher. They can chase shyness and start with the little they know and improve progressively sticking to English in their daily communication particularly at the college, focusing on what they wish to know but don't know. In this context, peer mentoring in different groups and clubs can play an important part so that they cannot be complexed. Besides, as a college is a place which hosts various talks and public speeches on various issues, attending them regularly would be an added advantage.

Conversely, teachers' part is needed to grapple with the challenges related to teaching university students ESP. Suggested remedies by respondents include the promotion of speaking practical exercises and focus on teaching and learning methodologies that integrate various strategies like using debate and discussions from small to larger groups. When this takes place, learners will have enough opportunities to participate and interact thus developing their speaking skills feeling confident. To help students get rid of the complex due to fear of practice and poor English, teachers should use simple vocabulary adapt it to the level of learners so that they cannot feel less confident but less perplexed with the teacher's expression. If this takes place, students can help learners express themselves thus developing their speaking skills which by and large seems hard for second language users. Effective class management and motivating learners by regularly using audio- visual aids, and integrating the use of technology in their language teaching to best attract learners. Teachers can by and large promote presentation and writing exercises.

The third question augurs the college's part to cope with these challenges militating against the effective teaching and learning of ESP. Respondents posited that efforts need be made to increase facilities like internet enough rooms and language laboratory. With the latter, students can familiarize with different accents and varieties of English they will be exposed to and know about the standard pronunciation. When there is internet, students' self-coaching can take place effectively and they can search what they want to at ease like videos, speeches and talks in English so that they can be familiar with and be exposed to English language and its culture. Audio- visual materials ought to be provided to facilitate teachers' teaching tasks where they have to handle bigger classes. With this materials, the teacher- students' interaction in class will not be affected as they said they have bigger classes. In similar vein, the college must set language practice policy within academic environment by reinforcing various clubs and internal competitions to motivate students. In the view of Elsadig Ali \& Ayman Hamad (2019), a club is an organization that fosters its members' speaking skills as they have the same purpose where they can speak joyfully, freely and tactically. If these clubs are well supported, students can benefit from them in terms of extra curriculum activities where students can express themselves freely and discuss among themselves using that language, hence enhancing communication skills in English. To cope with the teacher student-ratio, it is worth increasing the number of qualified teachers since most of respondents emphasized this idea. In case this is done, class management during the teaching and learning exercise will be carried out more effectively enabling participation. This can also be a remedy to the problem of large and mixed classes of different interests in a subject as Lenard and Lenard (2018) and learning environment in that context can be more or less conducive and the teacher can help learners in tandem with their learners' ability, know their problems and solve them accordingly.

\section{CONCLUSION AND RECOMMENDATION}

English language is taught in Rwandan higher education to serve for various communicative purposes viz academic, social, personal and interpersonal. Challenges affecting the teaching and learning of this international language are basically linked with individual learners and partly with learning environment. Mahendran (2019) confirmed to effectively teach English and workplace literacy skills, there is a need of a resourceful, reflective and proactive teacher demonstrating an ability to align the lesson with learners' levels or competency with their learning aspirations and keenness to learn. The author recommends active participation learning which he says "rekindles even the passive learners to get involved in a fun way to learn and practice language skills". A similar point is echoed in Lenard and Lenard (2018) that overcoming challenges impeding effective teaching and learning entails teaching in smaller student groups, more academic skill-based classes, better course books and a closer cooperation with subject specialists. The authors suggested a big part of school management in order to help improve ESP courses 
development and enhance the acquired skills quality of the future graduates. Researchers in this study are not far from these views for effective teaching and learning of ESP. For the most, the three parts concerned with the teaching and learning of English for Specific purposes (ESP) are required to play their part each. Students should feel responsible and avoid that fear of practice. Because "Practice makes perfect" they will improve gradually simply that "by mistakes we learn". They should also read enough and attend public talks delivered in English. For the teachers of ESP, a big duty lie in knowing their students' gaps and help them accordingly, giving them more opportunities to practise, from what they already know to what they (teachers) want them (students) to know; creating rooms for debates from smaller to larger groups. Teachers should also vary the teaching and learning methodologies and give enough rooms to practical oral and written exercises. This is in line with Gợlovó (2007) who proposes seven solutions to grapple with a series of difficulties for effective teaching and learning ESP in mixed classes in higher education suchs (1) to vary topics and content so that students are more likely to feel interested; (2) Set open-ended tasks so that learners may complete them according to their levels; (3) provide activities with varying degrees of difficulties so that sometimes even more advanced students may find them a challenge which will help them to increase their motivation; (4) Use pair and group works so that they may help one another; (5) Group them according to their levels so that no one will feel ashamed of his her performance; (6) Attend to particular individual difficulties and (7) provide additional materials to those who may need it.

As for the institution, it would be better if the class size issue is remedied to enable the teacher help each of the learners effectively. Facilities such as internet, audio - visual related tools and language laboratory should be availed. Clubs where English must be used as a medium of interaction should be enhanced too to enable learners be familiar with that language. Notwithstanding the results, researchers do not generalize as the study based on a small number of Science and social Science students. The researchers believe that there are other perceptions as regard the teaching and learning of ESP in higher Education. In this light, further studies would investigate into teachers' perceptions of teaching ESP in higher education to bridge the gaps herein.

\section{REFERENCES}

[1] Batuto, MA. Lourdes A. \& de la Pena Maria Morena E. (2019) Enhancing students' speaking competence through communicative language teaching method. International Journal of Recent Advances in Multidisciplinary Research. 6(8), 5107-5117.

[2] Bazimaziki, Gabriel (2018) Students' perceptions of using a foreign language in a mother tongue dominated environment: Contrastive analysis. International Journal for innovation Education and Research (IJIER).6(2), 01-12.

[3] Burkšaitienè Nijolè \& Šliogerienè, Jolita (2018) Students' Experience of Learning ESP: Findings from a Case Study in Lithuania. The Journal of Teaching English for Specific and Academic Purposes. 6(3), 489-500

[4] Duyen Can (2019) ESP Teacher's perceptions and practices of formative assessment: An institutional case study in Vietnam. American Journal of Humanities and Social Sciences Research (AJHSSR), 3(5), 143-148.

[5] Elsadig Ali Elsadig Elnadeef \& Ayman Hamad Elneil Hamadan Abdala( 2019) The Effectiveness of English Club as Free Speaking Activity Strategy in Fostering Speaking Skill in Saudi Arabia Context. International Journal of Linguistics, Literature and Translation (IJLLT). 2(1)231-236.

[6] Frankenberg-Garcia Ana (2018) Investigating the Collocations Available to EAP writers. Journal of English for Academic Purposes. 35 (2018), 93-104.

[7] Fry, H., Ketteridge,S.,\& Marchall, S. (Eds.) (2009) A Handbook for teachin and Learning in Higher Education: Enhancing Academic Practice, $3^{\text {rd }}$ ed.,New York: Routledge.

[8] Gớlovó, Dita (Ed.) (2007) Language for Specific Purposes: Searching for Common Solutions. Cambridge: CSP.

[9] Kimbouala Nkaya, Allembe Rodrigue Lézin and Moustapha Gilbert Salomon (2018) Language Teaching and Motivation: Factors Preventing EFL Learners from Effectively Learning English and Strategies to Motivating Learners. International Journal of Current Research.10 (11), 75292-75296.

[10] Le Van Tuye, \& Tran Thị Trang Loan (2019) Factors Affecting EFL Students' Willingness to Communicate in Speaking Classes at the Vietnamese Tertiary Level. International Journal of English Literature and Social Sciences. 4(2), 252-262.

[11] Lenard, D. Božić \& Lenard, I. (2018) Examining Pedagogical content knowledge of ESP teachers. The Journal of Teaching English for Specific and Academic Purpose. 6(3), 353-364.

[12] Mahendran, S. (2019) Learning English through Active Participation (LEAP). International Journal of English, Literature and Social Sciences (IJELS). 4(1), 135-139.

[13] Mohammad Qasim, AlTarawneh \& Eyad Ahmad, AlMithgal. (2019)Teachers' and Students' Perceptions of Using L1 in the ESP Classroom: a Case of Medical English at an Applied Medical College in Saudi Arabia. International Journal of Linguistics, Literature and Translation (IJLLT). 2(3), 19-35. 
[14] Morgan, Daryle, W. \& Krejcie, Robert, V. (1970) Determining Sample Size for Research Activities. Educational and Psychological Measurement.30, (607-610).

[15] Richards Jack, C. (2006) Communicative Language Teaching Today. Cambridge: Cambridge University Press.

[16] Rupert, W. (2016) Speaking Test Development in English for Academic Purpose: A Pilot study. University of Stirlling: British Council.

[17] Sumipo, Jasmin, M. (2019) The Reading Comprehension Levels of Grade 12 ABM Students: An ESP Design for Basic English Course. International Journal of English Literature and Social Sciences (IJELS), 4(1), 114-119.

[18] Tichie Ann Econg-Baena (2013) The Implementation of Communicative Language Teaching (CLT) Approach in English 1/101 towards a Faculty Development Program. (Available from http://eltweekly.com/2013/05/theimplementation-of-communicative-language-teaching-cltapproach-in-english-1101-towards-a-faculty-developmentprogram-by-tichie-ann-econg-baena/.

[19] Udu Titus Terver (2019) Effect of Communicative Language Teaching Approach on SS 2 Science Students' use of English Passives in Katsina-Ala Lga of Benue State, Nigeria. International Journal of English Literature and Social Sciences (IJELS), 4(2), 297-303. 